\title{
Análise comparada de três padrões prosódicos em francês e em português europeu
}

\author{
Lurdes de Castro Moutinho \\ Universidade de Aveiro \\ Jean-Pierre Zerling \\ Université Marc Bloch à Strasbourg
}

\section{Résumé}

Notre objectif est d'effectuer une comparaison entre trois types de structures prosodiques (déclarative, impérative et interrogative) réalisées dans deux langues romanes de type accentuel différent: le français (accent rythmique) et le portugais européen (accent lexical).

Pour chaque langue, le corpus est constitué d'une phrase lexicalement ambiguë prononcée par un locuteur masculin natif. Les phrases dans les deux langues ont une structure globale très voisine, afin de favoriser leur comparaison. Les paramètres retenus pour l'analyse sont la fréquence fondamentale Fo, la durée et l'intensité des voyelles. La comparaison porte d'une part sur les différences entre les trois structures prosodiques pour une même langue, puis sur les différences inter-langues pour un même patron prosodique.

Les conclusions montrent, au-delà des particularités individuelles propres aux locuteurs, et malgré la nature accentuelle différente des deux langues, que les stratégies prosodiques utilisées sont en fait très voisines pour la déclarative et l'impérative. En revanche, l'interrogative semble réalisée de manière très différente par les deux locuteurs, tous en présentant néanmoins certains points communs. 


\section{OBJETO DE ESTUDO}

7 sta pesquisa teve a sua origem no momento de uma visita de um dos autores deste artigo ao Centro de Línguas e Culturas da Universidade de Aveiro, onde foi realizado um workshop sobre análise prosódica, destinado a estudantes de Fonética.

Ela tem como objetivo:

- por um lado, comparar, para uma língua dada, três tipos de estruturas prosódicas:

- declarativa

- interrogativa

- imperativa

- por outro lado, repetir a análise para várias línguas românicas, neste caso o francês (FR) e o português europeu (PE) e, posteriormente, para o espanhol, o italiano, etc., a fim de serem realizados estudos comparativos. Os resultados destes trabalhos poderão ser comparados com os obtidos no âmbito do Atlas multimídia das línguas românicas (Grenoble, projeto AMPER ${ }^{1}$ ).

\section{PROCEDIMENTO EXPERIMENTAL}

\section{As diferentes etapas}

A pesquisa apresenta-se organizada em diversas etapas:

Para cada uma das línguas, teve o seguinte procedimento:

- escolha de uma frase para constituição do corpus, obedecendo a certas restrições;

- transcrição fonética da frase; 
- gravação por um falante;

- previsão dos acentos lexicais e rítmicos;

- previsão das variações melódicas, segundo a terminologia de Delattre (DELATTRE, 1966);

- observação das variações efetivamente realizadas e concordância com as previsões;

- comparação dos três padrões melódicos;

- análise das durações e da intensidade vocálicas.

Seguidamente, e cruzando os dados obtidos para as diferentes línguas estudadas, fez-se a determinação das particularidades e dos pontos comuns próprios a cada uma das línguas.

\section{O corpus}

Para a constituição do corpus do presente trabalho, foram construídas duas frases cujas estruturas, sintática e fonética, são relativamente próximas:

Pateta toca no café

Petitout passe à la télé [paitete 1tokenuka1fe]

[pətiıtu pasalateıle]

Como podemos constatar, tratando-se de duas frases ambíguas, apenas a variação prosódica permitirá, no nível da oralidade, a distinção de sentido em cada uma das modalidades escolhidas: declarativa, imperativa e interrogativa.

No plano segmental, as frases são comparáveis, visto ambas conterem o mesmo número de sílabas fonéticas. As sílabas são abertas, de estrutura CV, e, quase sempre, a consoante que integra a sílaba é uma consoante surda, com o objetivo de facilitar a análise. Note-se que, no caso do francês, esta constituição silábica não favorece o alongamento vocálico.

As diferenças fundamentais entre as frases advêm do fato da sílaba acentuada, no caso dos nomes próprios, não coincidir nas duas línguas e o verbo ser dissilábico em português e monossilábico em 
francês. No entanto, e com o objetivo de tornar as duas frases o mais semelhantes possível, escolhemos como último elemento da frase em português uma palavra oxítona acentuada e, por isso, na última sílaba, como sempre acontece com o francês. Para além disso, esta opção permite, simultaneamente, evitar a queda da última vogal na frase portuguesa. Na verdade, estudos anteriores (DELGADO-MARTINS, 1982; MIRA MATEUS et al, 1982; MORAIS BARBOSA, 1994) mostram que as vogais átonas do português europeu, quando em final de sílaba ou de frase, sofrem, freqüentemente, um fenômeno de queda. Estudos por nós realizados (MOUTINHO et al. 2001), comprovam esse tipo de fenômeno, sobretudo em frases do tipo declarativo.

\section{Os documentos}

Para cada uma das línguas, as frases são produzidas várias vezes pelo mesmo falante nativo, do sexo masculino. Para esta análise, foram seleccionadas cinco realizações, para cada tipo de frase, consideradas perceptivamente corretas e consideradas representativas das modalidades em estudo. Dispomos, por isso, de um total de 3 x $5=15$ realizações de cada frase, para cada uma das línguas.

As gravações foram realizadas, respectivamente, nos laboratórios de fonética das Universidades de Aveiro (Portugal) e Estrasburgo (França). O sinal gravado foi convertido no formato ".wav", de modo a poder ser tratado posteriormente de forma semi-automática.

A segmentação do sinal, bem como a elaboração de gráficos, foram realizadas em Aveiro, utilizando o programa Matlab e tendo sido adotada uma metodologia cientificamente testada (CONTINI et al. 2002, MOUTINHO et al. 2001). ${ }^{2}$

Os parâmetros analisados para cada realização vocálica são a duração, a intensidade e três valores da freqüência fundamental, medidos em três pontos distintos: princípio, meio e fim da vogal. Os valores médios obtidos, para as cinco realizações de uma mesma frase pelo mesmo falante, são calculados em seguida. São esses mesmos valores, inscritos nos quadros fornecidos em anexo, que serão utilizados para a análise. 
Os gráficos representam, para cada frase, as variações sobrepostas da frequência fundamental, Fo, para todas as vogais realizadas. A linha média de Fo é calculada a partir de cinco frases, para cada um dos padrões prosódicos.

Outros gráficos representam, para cada frase, as variações médias da freqüência fundamental Fo para cada um dos padrões prosódicos. São estas variações médias da curva melódica que serão, em seguida, comparados, quer para dois padrões entoacionais do mesmo falante, quer ainda para o mesmo padrão nas duas línguas.

Finalmente, diversos gráficos permitirão comparar as variações de duração e intensidade das vogais.

\section{Cálculo do desvio tonal}

Para comparar as variações ou os valores da freqüência fundamental, optamos por trabalhar em semitons temperados, partindo da fórmula:

$$
F_{2}=F_{1}(122)^{x}
$$

que permite calcular, a partir de uma freqüência $F_{1}$, a freqüência $F_{2}$ situada $\mathrm{x}$ semitons mais altos, permitindo calcular o valor do desvio tonal $x$ (em semitons):

$$
\mathrm{x}=(12 / \log 2) \cdot \log \left(\mathrm{F}_{2} / \mathrm{F}_{1}\right)=39,86 \cdot \log \left(\mathrm{F}_{2} / \mathrm{F}_{1}\right),
$$

que podemos aproximar de $\mathbf{x}=\mathbf{4 0 .} \log \left(\mathbf{F}_{\mathbf{2}} / \mathbf{F}_{\mathbf{1}}\right)$

\section{ANÁLISE}

\section{Considerações preliminares: comparação dos dois locutores}

Em primeiro lugar, parece-nos interessante fazer uma breve análise comparativa dos dois falantes. Globalmente, observam-se dois tipos de diferenças sistemáticas:

- registro;

- tessitura;

- velocidade de produção de fala. 


\section{- registro}

Denomina-se, geralmente, de registro a altura característica da voz de um cantor, no interior do seu alcance vocal: o registro agudo, alto, médio e grave.

Embora os nossos dois falantes sejam homens, o seu registro é ligeiramente diferente. O quadro que se segue permite comparar a freqüência fundamental média, Fo, calculada para cada um deles a partir de todas as vogais $(8 \times 5=40)$ e para cada tipo de frase. A última linha do quadro indica o desvio médio entre as duas vozes, convertido em semitons temperados.

Quadro 1 - Freqüência fundamental média dos dois locutores para as três frases

\begin{tabular}{|l|c|c|c|c|c|c|c|}
\hline $\begin{array}{c}\text { Fo médio } \\
(\mathrm{Hz} / \text { nota) }\end{array}$ & \multicolumn{3}{|c|}{ Declarativa } & \multicolumn{3}{|c|}{ Imperativa } & \multicolumn{2}{c|}{ Interrogativa } & $\begin{array}{c}\text { ?Fo } \\
\text { (D/Im-In) }\end{array}$ \\
\hline falante FR & 154 & ré\# & 153 & ré\# & 181 & fa & $2,9 \mathrm{dt}$ \\
\hline falante PT & 122 & si & 124 & si & 146 & ré & $3 \mathrm{dt}$ \\
\hline ?Fo médio (FR/PT) & $4 \mathrm{dt}$ & & $3,6 \mathrm{dt}$ & & $3,7 \mathrm{dt}$ & & \\
\hline
\end{tabular}

Note-se que o falante português fala, sistematicamente, com uma freqüência fundamental média mais baixa de 3,6 a 4 semitons do que o falante francês, independentemente do tipo de frase.

Por outro lado, a frase interrogativa é produzida, globalmente, pelos dois falantes, com uma vOz mais elevada de 3 semitons, relativamente ao que acontece com as frases declarativa e interrogativa (última coluna).

\section{- a tessitura}

Devemos assinalar que, no presente trabalho, atribuiremos a tessitura um sentido mais amplo do que normalmente lhe é atribuído: o alcance de uma voz que vai da nota mais grave à nota mais aguda e a escala de sons que podem ser emitidos por uma voz, sem qualquer dificuldade.

No quadro seguinte, indicamos, para cada falante e para cada tipo de frase, os valores extremos atingidos para a freqüência fundamental (em Hz), o equivalente aproximado em termos de notas 
musicais, bem como o desvio correspondente, em semitons, calculado segundo o método anteriormente descrito.

Em seguida, avaliamos o desvio em semitons entre os dois falantes, respectivamente para o Fo mais baixo (mínimo) e o Fo mais alto (máximo), bem como o intervalo entre esses valores.

O gráfico ilustra, com base nos valores inscritos no quadro, em termos de notas musicais, a tessitura própria a cada um dos falantes.

Quadro 2 - Valores extremos da freqüência fundamental e tessitura dos dois falantes para as três frases

\begin{tabular}{|c|c|c|c|c|}
\hline & & Declarativa & Imperativa & Interrogativa \\
\hline Falante FR & $\begin{array}{l}\text { Fo mini a maxi } \\
\text { notas mini a maxi } \\
\text { tessitura en } \mathrm{dt}\end{array}$ & $\begin{array}{l}94 \text { à } 227 \mathrm{~Hz} \\
\mathrm{Fa} 1 \#+\mathrm{a} \mathrm{La} 2+ \\
=15,3 \mathrm{dt}\end{array}$ & $\begin{array}{l}101 \text { a } 221 \mathrm{~Hz} \\
\text { Sol1 a La2 } \\
=13,6 \mathrm{dt}\end{array}$ & $\begin{array}{l}125 \text { à } 270 \mathrm{~Hz} \\
\text { Si1 a Do3 } \\
=13,3 \mathrm{dt}\end{array}$ \\
\hline Falante PT & $\begin{array}{l}\text { Fo mini a maxi } \\
\text { notas mini a maxi } \\
\text { tessitura en } \mathrm{dt}\end{array}$ & $\begin{array}{l}91 \text { a } 144 \mathrm{~Hz} \\
\text { Fa1\#- a Do2\#+ } \\
=7,9 \mathrm{dt}\end{array}$ & $\begin{array}{l}92 \text { a } 163 \mathrm{~Hz} \\
\text { Fa1\# a Ré2\#+ } \\
=9,9 \mathrm{dt}\end{array}$ & $\begin{array}{l}108 \text { a } 185 \mathrm{~Hz} \\
\text { Sol1\#+ a Fa2\# } \\
=9,3 \mathrm{dt}\end{array}$ \\
\hline Desvios FR/PT & $\begin{array}{l}\text { ?Fo mini } \\
\text { ?Fo maxi } \\
\text { ? tessitura }\end{array}$ & $\begin{array}{l}0,6 \mathrm{dt} \\
7,9 \mathrm{dt} \\
7,4 \mathrm{dt}\end{array}$ & $\begin{array}{l}1,6 \mathrm{dt} \\
5,3 \mathrm{dt} \\
3,7 \mathrm{dt}\end{array}$ & $\begin{array}{l}2,5 \mathrm{dt} \\
6,5 \mathrm{dt} \\
6,8 \mathrm{dt}\end{array}$ \\
\hline
\end{tabular}

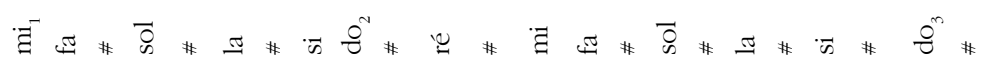

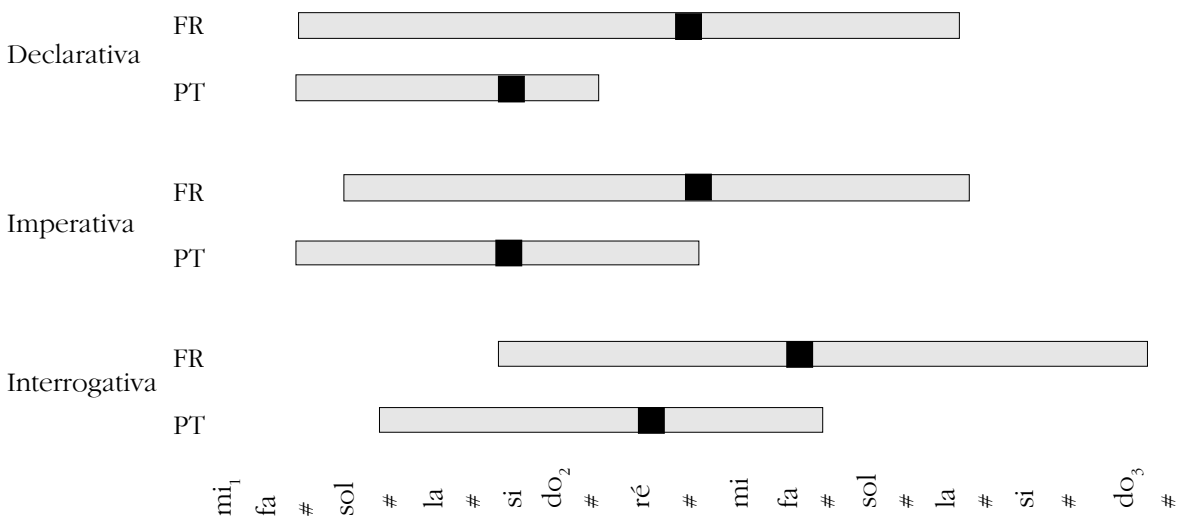

Figura 1 - Tessitura média dos dois falantes para a produção das três frases (A parte mais escura na barra indica a medida média de Fo) 
As notas musicais emitidas pelos informantes são bastante próximas (Fa1\#) e levar-nos-iam a classificá-los, a ambos, se nos reportarmos aos critérios relacionados com o canto, como barítonos.

Para além disso, o fato mais marcante que pode ser observado no quadro 2 é a diferente tessitura que caracteriza a voz de cada um dos locutores, variando de 3,7 a 7,4 semitons. A tessitura do falante francês, compreendida entre 13,3 e 15,3 semitons, é sistematicamente superior, atingindo o dobro da do português, compreendida entre 7,9 et 9,9 semitons. Este último apresenta-se, por isso, com uma entoação mais monótona.

As considerações que acabamos de tecer devem ser relacionadas com as observações efetuadas a partir dos valores médios de Fo, inscritos no quadro precedente. Os valores médios superiores, relativamente ao falante francês, não refletem uma voz sistematicamente com colocação mais elevada, visto que os valores inferiores dos dois informantes são próximos entre si, mas refletem sobretudo uma grande variabilidade da freqüência fundamental.

\section{- o débito e as durações}

A audição e a observação do sinal acústico gravado revelam a presença de uma pausa entre dois grupos rítmicos, somente no caso da frase imperativa, em todas as vezes que ela é realizada por qualquer um dos falantes.

O quadro 3 resume o conjunto dos dados: podemos observar a duração total de cada uma das frases, a duração do tempo de pausa, a relação entre a pausa e o tempo de elocução (duração total), a média destes valores, para cada falante e, finalmente, o cálculo da velocidade de elocução (com as pausas), bem como a duração do sinal de fala (sem pausas).

Constatamos que o falante português articula os sons um pouco mais rapidamente que o falante francês (6,7 sílabas por segundo e 6,4 silabas por segundo, respectivamente). Por outro lado, a pausa efetuada pelo primeiro é claramente mais longa (17,1\% da duração total da frase, para o português, $5,3 \%$, para o francês). No entanto, se tivermos em 
conta as pausas, é o falante francês que terá uma velocidade de elocução global ligeiramente mais rápida, com 6 sílabas por segundo, em oposição ao português que realiza 5,5 por segundo.

Quadro 3 - Frases imperativas - duração total das frases e das pausas

\begin{tabular}{|c|c|c|c|c|c|c|c|}
\hline \multicolumn{4}{|c|}{ FR } & \multicolumn{4}{|c|}{ PT } \\
\hline frase & duração & pausa & pausa/dur & frase & duração & pausa & pausa/dur \\
\hline 1 & 1376 & 64 & $4.6 \%$ & 1 & 1416 & 261 & $18.4 \%$ \\
\hline 2 & 1263 & 68 & $5.4 \%$ & 2 & 1446 & 240 & $16.6 \%$ \\
\hline 3 & 1358 & 71 & $5.2 \%$ & 3 & 1467 & 249 & $17.0 \%$ \\
\hline 4 & 1320 & 72 & $5.4 \%$ & 4 & 1456 & 256 & $17.6 \%$ \\
\hline 5 & 1320 & 77 & $5.8 \%$ & 5 & 1446 & 230 & $15.9 \%$ \\
\hline $\begin{array}{l}\text { Tot } \\
\text { Desvio }\end{array}$ & $\begin{array}{l}1327 \\
43.5 \\
\end{array}$ & $\begin{array}{l}70 \\
4.9\end{array}$ & $5.3 \%$ & $\begin{array}{c}\text { Tot } \\
\text { Desvio }\end{array}$ & $\begin{array}{l}1446 \\
19.0\end{array}$ & $\begin{array}{l}247 \\
12.5\end{array}$ & $17.1 \%$ \\
\hline sil/seg & 6.0 & & & sil/seg & 5.5 & & \\
\hline $\begin{array}{l}\text { dur.fala } \\
\text { sil/seg }\end{array}$ & $\begin{array}{c}1257 \\
6.4\end{array}$ & & & $\begin{array}{l}\text { durfala } \\
\text { sil/seg }\end{array}$ & $\begin{array}{c}1199 \\
\mathbf{6 . 7}\end{array}$ & & \\
\hline
\end{tabular}

Esta tendência de um débito global ligeiramente mais rápido, por parte do falante francês, confirma-se no quadro seguinte, onde podemos comparar as durações médias para os três tipos de frase. A diferença é, no entanto, mínima, visto que a variação se situa entre 0,3 e 0, 6 sílabas por segundo.

Quadro 4 - Duração média das frases e velocidade de elocução (+ com pausas)

\begin{tabular}{|r|c|c|c|c|c|c|}
\hline & \multicolumn{3}{|c|}{ FR } & \multicolumn{3}{c|}{ PT } \\
\hline & $\begin{array}{c}\text { tempo } \\
\text { de fala }\end{array}$ & $\begin{array}{c}\text { velocidade } \\
\text { de elocução }\end{array}$ & $\begin{array}{c}\text { velocidade } \\
\text { deelocução }\end{array}$ & $\begin{array}{c}\text { tempo } \\
\text { de fala }\end{array}$ & $\begin{array}{c}\text { velocidade } \\
\text { de elocução }\end{array}$ & $\begin{array}{c}\text { velocidade } \\
\text { de elocução }\end{array}$ \\
\hline Declarativa & 1137 & $\mathbf{7 . 0}$ & & 1247 & 6.4 & \\
\hline Imperativa & 1257 & 6.4 & & 1199 & $\mathbf{6 . 7}$ & \\
\hline + pausas & 1327 & & $\mathbf{6 . 0}$ & 1446 & & 5.5 \\
\hline Interrogativa & 1177 & $\mathbf{6 . 8}$ & & 1243 & 6.4 & \\
\hline
\end{tabular}

Poderemos verificar, nos quadros fornecidos em anexo, que as durações vocálicas são inferiores para o falante francês, o que não deixa de ser surpreendente, visto que a sua velocidade de elocução 
é ligeiramente superior. Constatamos, também, que as durações vocálicas mais baixas são, em geral, e para cada uma das frases, de 40ms para o falante francês e de 30ms para o português. Retomaremos o estudo desse fenômeno, de forma mais aprofundada, um pouco mais adiante.

\section{- a intensidade}

Globalmente, a intensidade média das vogais dos dois locutores apresenta-se bastante estável, oscilando entre 95 e 105 dB. Em português, há uma tendência para descer em final de frase, o mesmo não acontecendo no francês. Também este aspecto será retomado no desenvolvimento da análise.

\section{Estudo das variações melódicas (Fo)}

\subsection{Frase declarativa}

\section{- previsão do padrão melódico}

Para a declarativa, o padrão entoacional esperado é globalmente descendente (padrão de "finalidade", segundo Delattre, 1966). Mas as frases por nós analisadas, incluindo, a priori, dois grupos rítmicos, o primeiro grupo pode ser ascendente. Para além disso, poderemos ainda esperar outras eventuais variações, relacionadas com os acentos lexicais, para o português, pela utilização de um ou vários dos três parâmetros acústicos: Fo, duração ou intensidade.

\section{- falante francês}

Os resultados vão de encontro às nossas previsões: verifica-se uma subida melódica de 8 semitons (143-227 Hz) no primeiro grupo. Note-se que, apesar desta subida, cada segmento vocálico se apresenta, freqüentemente, descendente. Este aspecto está ligado a um fenômeno micro-prosódico, muito freqüente em francês: o ataque glotal é reforçado pela presença de uma consoante surda que antecede a vogal. O ponto culminante $(227 \mathrm{~Hz})$ é atingido na $3^{\mathrm{a}}$ sílaba (fim do grupo rítmico), constatando-se, em seguida, uma descida regular, quase linear de 12,6 semitons (195-94 Hz). Relativamente às 
durações, verifica-se que as duas sílabas, finais de grupo, são ligeiramente mais longas do que as outras, sobretudo a última que chega quase a atingir o dobro da duração.

\section{- falante português}

Constatamos igualmente uma subida nas três primeiras sílabas, embora proporcionalmente menor do que em francês: 3,6 semitons $(118-145 \mathrm{~Hz})$. A elevada freqüência sobre a vogal átona final pode parecer surpreendente, mas confirma o papel que ela desempenha no plano entoacional, tal como acontece em francês. As duas sílabas de toca mantêm-se elevadas e encontram-se ao mesmo nível. Assistimos, em seguida, a uma descida progressiva de 7,7 semitons $(142-91 \mathrm{~Hz})$ nas três últimas sílabas. Note-se que as três vogais acentuadas são as mais longas, sobretudo a última, sendo a sua duração 2 ou 3 vezes superior à duração observada para as breves. No entanto, e contrariamente a uma expectativa legítima, a freqüência fundamental não permite identificar verdadeiramente o que normalmente são considerados "acentos tônicos".

\section{- comparação Português/Francês}

A sobreposição da representação das curvas melódicas obtidas mostra claramente a semelhança entre dois padrões entoacionais escolhidos em ambas as línguas. ${ }^{3}$ Mas notamos igualmente, independentemente da diferença existente, no nível da tessitura, entre os dois informantes, que a subida do primeiro grupo é claramente superior em francês. Este tipo de realização é perfeitamente compreensível, visto que a terceira sílaba, em francês, é, simultaneamente, portadora do acento rítmico e do padrão entoacional de continuação do movimento. Em português, pelo contrário, a presença do acento sobre a segunda sílaba dificulta, certamente, uma subida sobre a terceira, o que poderia provocar uma eventual ambigüidade. 


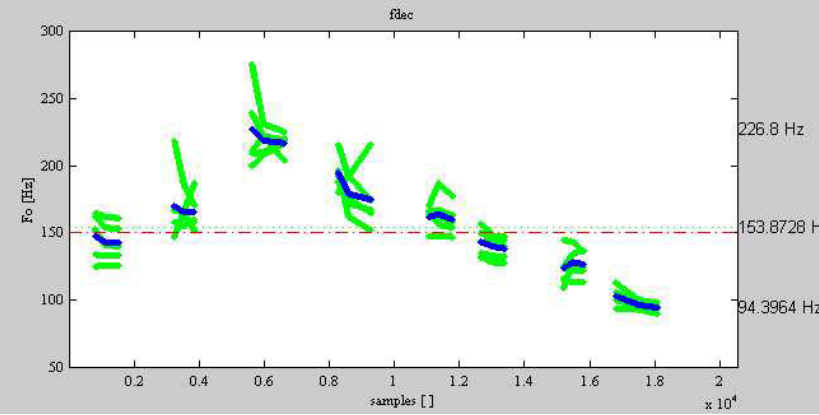

Figura 1 - Média das 5 repetições da frase: Petitout passe à la télé - francês - Declarativa

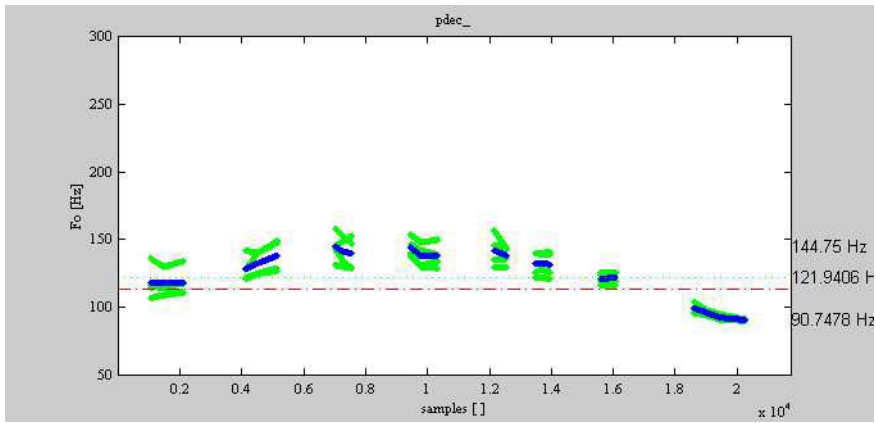

Figura 2 - Média das 5 repetições da frase: Pateta toca no café - português - Declarativa

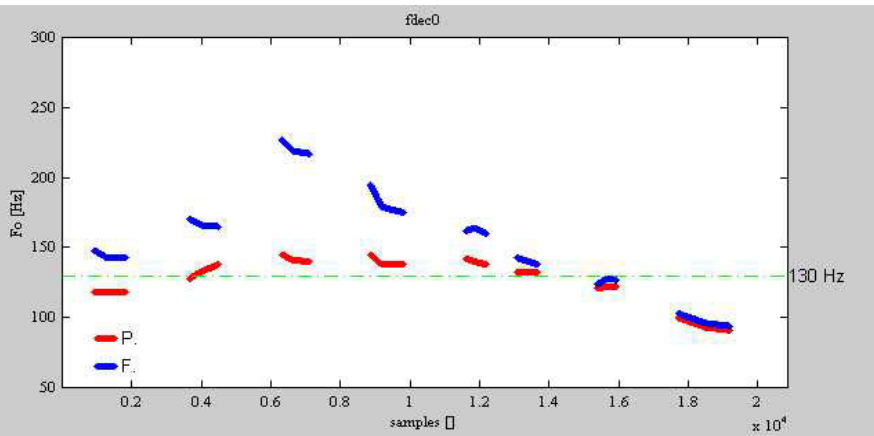

Figura 3 - Comparação das Declarativas PORT/FR 


\subsection{Frase imperativa}

\section{- previsão do padrão melódico}

A frase imperativa (a ordem ou "commandement", segundo a terminologia de Delattre) obedece geralmente a um padrão descendente. No entanto, as nossas frases comportam dois grupos rítmicos, materializando dois sintagmas que, gramaticalmente, correspondem a um vocativo, seguidas de um imperativo. $\mathrm{O}$ primeiro elemento (vocativo) poderia perfeitamente ser realizado, tanto por um movimento elevado ou ascendente (do tipo interpelativo), como por um movimento descendente (do tipo exclamativo).

\section{- falante francês}

De certa forma interessante, relativamente às nossas previsões, constatamos que a curva melódica do segmento vocativo é globalmente ascendente, 4,3 semitons (130-167 Hz), mas se a terceira vogal é marcada por um ataque elevado, o esquema inverte-se rapidamente e a freqüência desce claramente de 2,1 semitons (167-148), o que se torna possível devido a uma longa duração da vogal. Tudo se processa como se tivéssemos, simultaneamente, neste primeiro grupo, uma subida e uma descida combinadas de Fo. A longa duração da terceira vogal reflete, também, sem sombra de dúvida, o fim de um grupo rítmico mais marcado do que na declarativa, tanto mais que esse mesmo grupo é seguido de uma pausa silenciosa.

Podemos admitir que esta descida desempenha uma função contrastiva, visando ainda evidenciar o ataque muito elevado, no que diz respeito à freqüência sobre a primeira sílaba do grupo imperativo. A subida brusca de 148 para $221 \mathrm{~Hz}$ equivale a 6,9 semitons, o que é verdadeiramente considerável.

A variação melódica do segundo grupo faz-nos pensar na frase declarativa, isto é, com uma descida progressiva de 13,6 semitons (221-101 Hz). 


\section{- falante português}

Podemos dizer que, para este falante, o grupo entoacional que corresponde ao vocativo - $1^{\circ}$ grupo rítmico - é, simultaneamente, semelhante e diferente do observado para o informante francês: de fato, constatamos duas variações contraditórias. Se, em francês, a curva melódica é globalmente ascendente com uma descida final, para o português, poderemos dizer que há globalmente uma descida, com uma subida intermédia, necessária para marcar o acento tónico sobre o paroxítono Pateta. Esta descida é importante, visto que representa uma diferença de 4 semitons $(120-95 \mathrm{~Hz})$ entre o início e o fim deste grupo rítmico, chegando mesmo a atingir uma diferença de 7,1 semitons $(143-95 \mathrm{~Hz})$, se tomarmos como ponto de partida, o ponto mais elevado da $2^{a}$ vogal. Esta descida é tanto mais importante, por quanto ela conduz a curva melódica ao seu ponto mínimo $(95 \mathrm{~Hz})$, que apenas voltaremos a encontrar no final de frase.

O grupo seguinte, como em francês, surge depois de uma pausa (mais longa para este informante) e um ataque ainda mais marcado do que se verifica no falante francês: 9,3 semitons mais elevado (95-163 Hz). Este fato é tanto mais significativo, porque o falante português utiliza menos as variações melódicas do que o francês. Recorde-se que a sua tessitura se situa entre 7,9 e 9,9 semitons. Constatamos que mobiliza, nesta situação precisa, todas as suas capacidades vocais, visto que a sua freqüência fundamental passa, praticamente, do seu valor mais baixo ao seu valor mais elevado.

À semelhança do que acontece com a declarativa, verificamos que as três vogais acentuadas são as mais longas, embora, neste caso, seja a segunda, em Pateta, que é a mais longa (cerca de 4 vezes mais longa do que as breves). Tal fato é compreensível, na medida em que o vocativo se apresenta como elemento importante. Contrariamente ao que se passa com a declarativa, a freqüência fundamental desempenha, neste caso, um papel mais relevante, por permitir destacar os acentos "tônicos", duas das vezes, através de pontos culminantes e, uma outra vez, pela descida final. 


\section{- comparação português/francês}

A sobreposição das duas curvas melódicas mostra-se, claramente, e relativizando o efeito tessitura, diferente em cada um dos informantes, à semelhança dos dois padrões entoacionais nas duas línguas. O primeiro grupo apresenta um padrão convexo, com o seu valor máximo sobre a vogal acentuada, variando em função da língua. Em seguida, depois de uma pausa, a freqüência fundamental ataca o segundo grupo, com um valor muito elevado nos dois casos. O valor mais elevado em francês é, sem dúvida, condicionado pela já elevada freqüência da última vogal do grupo precedente. Recorde-se, no entanto, que, em termos de altura musical, o início deste movimento ascendente é superior em português. O final da frase é, em seguida, progressivamente descendente, constatando-se quase uma sobreposição do traçado para os dois falantes.

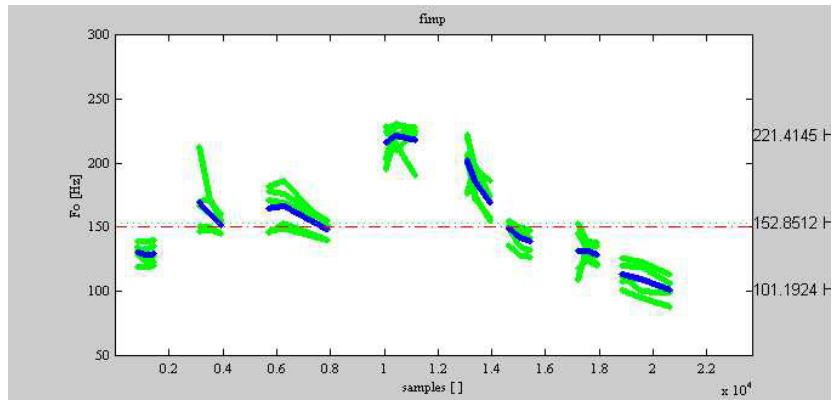

Figura 4 - Média das 5 repetições da frase: Petitout passe à la télé

- francês - Imperativa

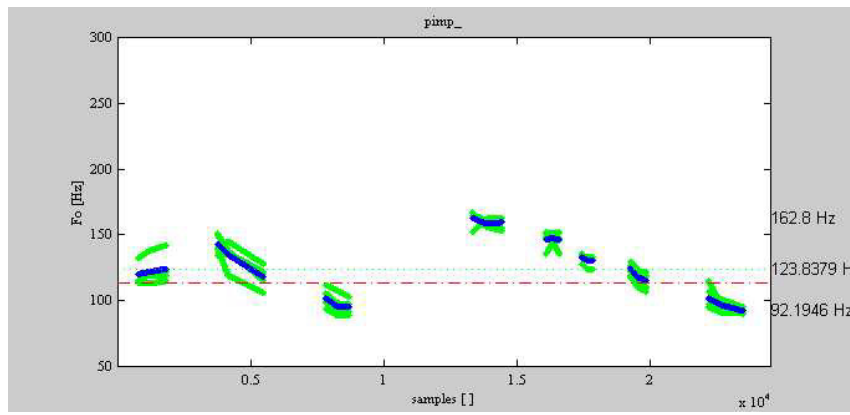

Figura 5 - Média das 5 repetições da frase: Pateta toca no café - português - Imperativa 


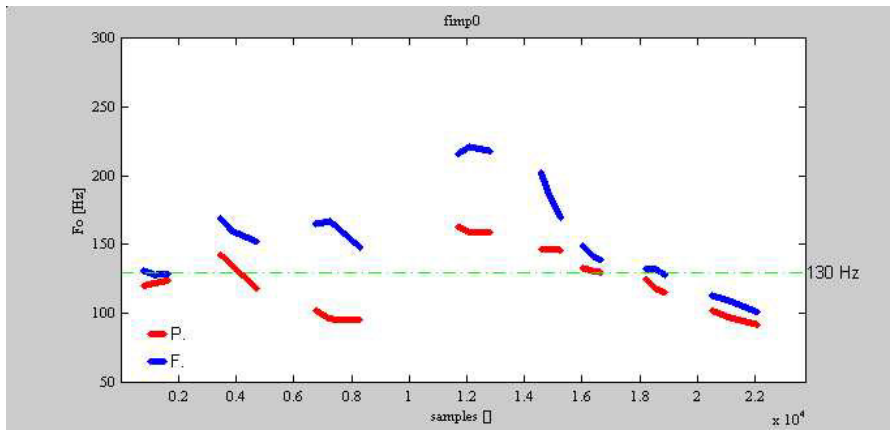

Figura 6-Comparação das imperativas PORT/FR

\subsection{Frase interrogativa}

\section{- previsão do padrão melódico}

Nas frases por nós analisadas, sendo sintaticamente ambíguas, sabemos que a entoação desempenha um papel necessariamente determinante. Neste caso, estamos perante uma interrogativa global (uma pergunta, "question", segundo Delattre), o que permite prever uma subida melódica, habitualmente próxima do final de frase. Esta frase sendo, à priori, constituída por dois grupos rítmicos, o primeiro é menos previsível: tanto pode ser ascendente, como descendente, de acordo com a lógica adotada (esquema ascendente de continuação ou descendente, para ser obtido um efeito contrastivo). Acrescentese a tudo isto as variações acentuais, já referidas.

\section{- falante francês}

Como para os dois tipos de frase precedentes, constatamos que a freqüência fundamental sobe gradualmente sobre as três primeiras sílabas que constituem a palavra Petitout, com uma tessitura de 3,5 semitons (125-153 Hz), próximo da frase imperativa, mas com uma mudança de direção menos acentuada e uma duração mais longa da última vogal do grupo. Em seguida, e depois de uma variação quase nula, na primeira metade do segundo grupo, assistimos a uma subida rápida e abrupta de Fo sobre a vogal final que se apresenta com uma 
longa duração: subida de 8,6 semitons (165-271 Hz), dos quais 5,3 (200-271 Hz) sobre a única vogal! A freqüência atingida é a mais elevada das três realizações $(271 \mathrm{~Hz})$, resultado que vai de encontro ao nível final proposto por Delattre, para o esquema entoacional de uma pergunta.

\section{- falante português}

O ataque da freqüência fundamental é o mais elevado das três frases produzidas por este falante $(161 \mathrm{~Hz}$, em oposição a 118 et 120 $\mathrm{Hz}$ ). Apresenta-se mesmo como praticamente mais elevado do que os máximos das duas frases precedentes (145 et $163 \mathrm{~Hz}$ ). Em seguida, depois de uma ligeira subida de 2,4 semitons (161-185 Hz) que culmina na vogal tônica, observa-se uma descida progressiva, muito lenta, até a vogal final que sofre uma queda abrupta de 4,6 semitons $(147-113 \mathrm{~Hz})$. No entanto, sensivelmente a meio da sua duração, assistimos a uma inversão do seu movimento, para subir de 1,4 semitons (108-117 Hz). Poderemos admitir que esta subida ligeira, ligada ao movimento de inflexão, é suficiente e determinante para provocar o efeito desejado: a percepção da subida final, característica da pergunta.

\section{- comparação português/francês}

De forma inequívoca, a sobreposição dos dois esquemas melódicos permite-nos observar que os dois falantes utilizam duas estratégias muito diferentes, quando fazem uma pergunta: em francês, ataque bastante baixo e subida progressiva até um arranque final muito marcado; em português, ataque relativamente elevado e descida progressiva até ao momento de uma ligeira inversão do movimento, seguida de subida final.

Globalmente, temos praticamente duas curvas simétricas, relativamente à linha horizontal, passando pela freqüência média das vogais situadas em meio de frase. Apesar das diferenças constatadas, existem pontos comuns: em início de frase, com um ataque ascendente nas duas línguas; em final, uma subida incidindo sobre a totalidade ou uma parte da última vogal. 


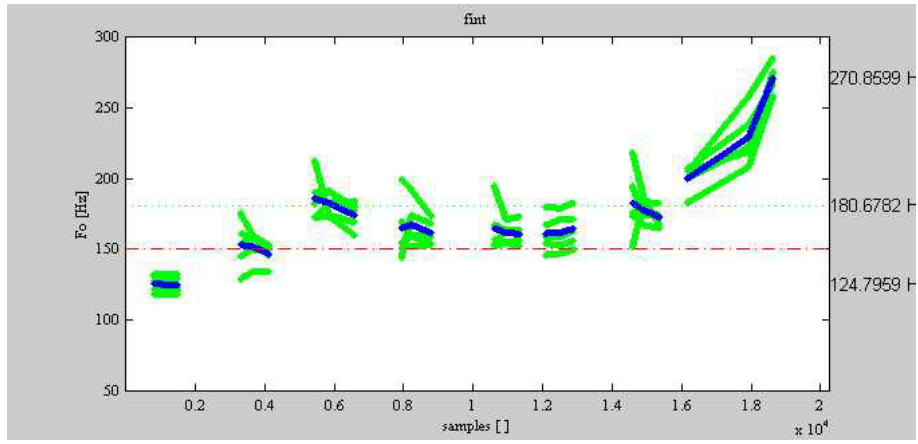

Figura 7 - Média das 5 repetições da frase: Petitout passe à la télé - francês - interrogativa

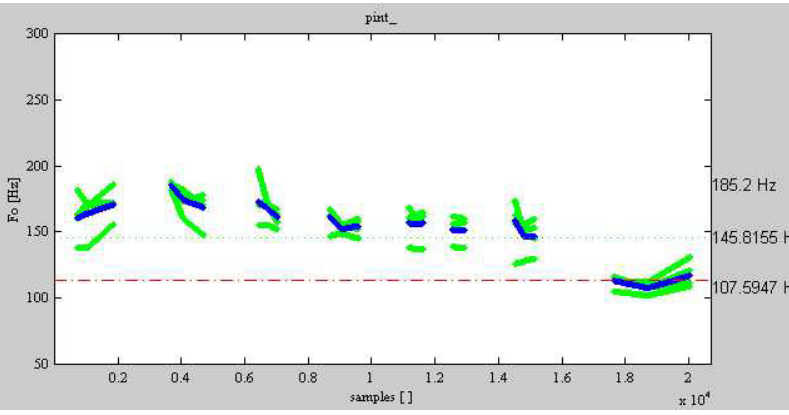

Figura 8 - Média das 5 repetições da frase: Pateta toca no café - português - interrogativa

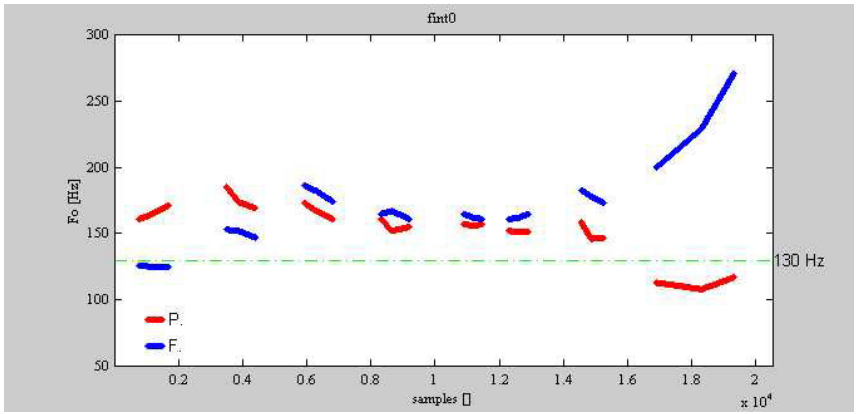

Figura 9 - Comparação das interrogativas PORT/FR 


\subsection{Variações intralocutores}

Os gráficos que se seguem permitem comparar as variações de Fo, para cada um dos falantes, não só entre as frases declarativa e a imperativa, mas também entre as frases declarativa e a interrogativa

Através da sobreposição da declarativa-imperativa, constatase, em ambas as línguas, um comportamento bastante aproximado, apesar das diferenças individuais assinaladas. Na primeira parte da frase, Fo sobe para a declarativa, enquanto que Fo tem tendência para descer ou a inverter-se, na imperativa.

No segundo grupo rítmico, após um ataque sobre a primeira vogal da imperativa, a curva é descendente e praticamente sobreposta quando da realização das quatro últimas vogais.

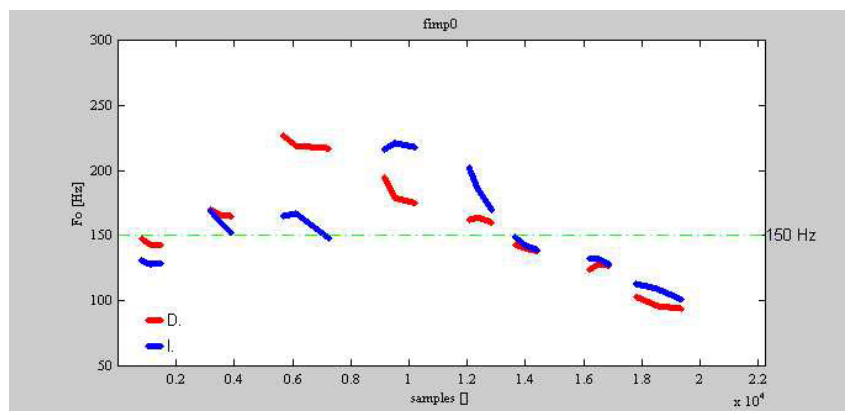

Figura 10 - Comparação entre a Declarativa e a Imperativa - falante francês Frase: Petitout passe à la télé

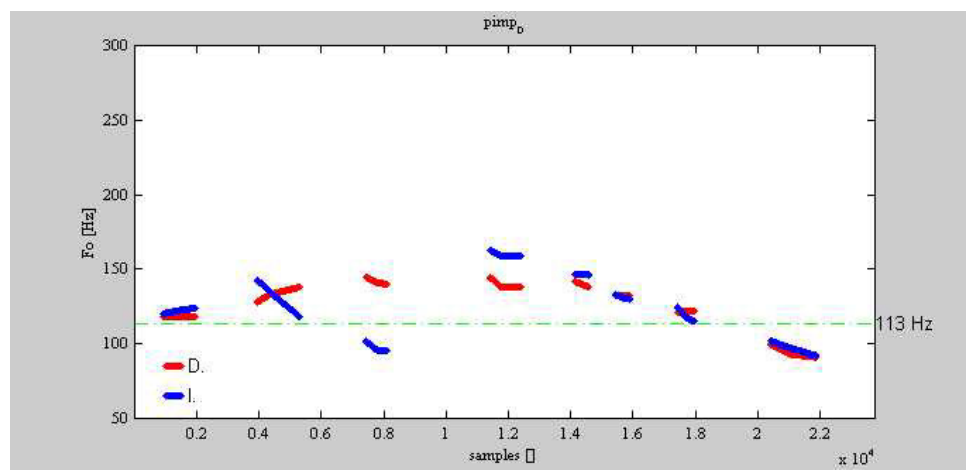

Figura 11 - Comparação entre a Declarativa e a Imperativa - falante português Frase: Pateta toca no café 
A sobreposição da declarativa-interrogativa confirma claramente as afirmações precedentes: a utilização de estratégias radicalmente diferentes nas duas línguas, relativamente à interrogativa:

- Em francês, o primeiro grupo rítmico sobe igualmente nos dois casos, mas com um valor da freqüência fundamental ligeiramente mais elevado, no caso da declarativa (de 2 a 3 semitons sobre as três primeiras vogais). Este fenômeno pode talvez dever-se ao fato de que, neste caso, os dois elementos da frase são mais independentes do ponto de vista sintático, enquanto que, no caso da interrogativa, haveria uma maior coesão entre os grupos.

- Em Português, a curva melódica global dos dois tipos de frase é quase paralela, mas, desta vez, com um Fo sistematicamente mais elevado em toda a frase interrogativa (um máximo de 5,6 semitons (118/164 Hz), no início; de 2,3 semitons (151/132 Hz) no resto da frase). A distinção entre os dois tipos de frase, no plano melódico, parece dever-se, essencialmente, a esta diferença de altura, sobretudo no ataque inicial e ainda a uma ligeira inversão ascendente sobre a última vogal, na frase interrogativa.

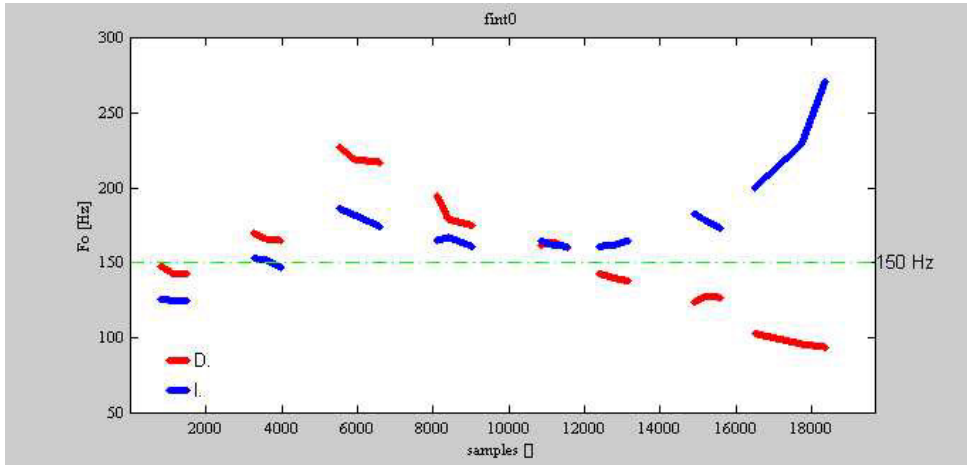

Figura 12 - Comparação entre a Declarativa e a Interrogativa - falante francês Frase: Petitout passe à la télé 


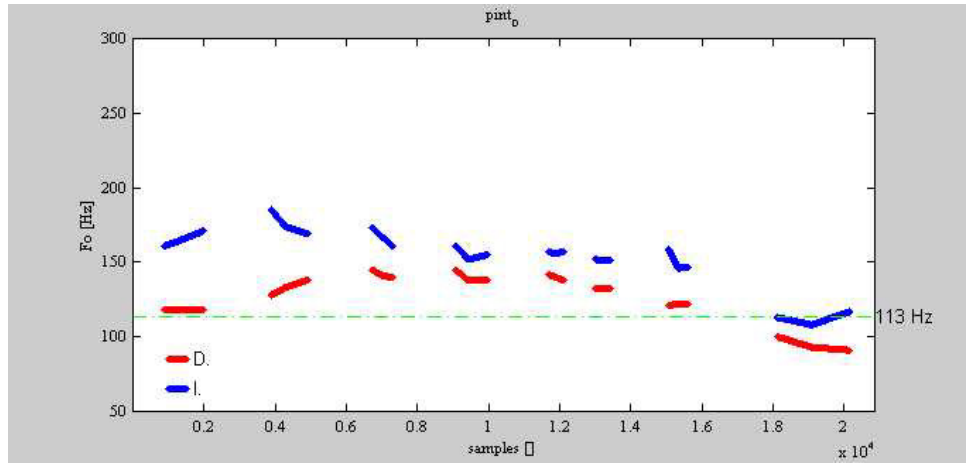

Figura 13 - Comparação entre a Declarativa e a Interrogativa - falante português Frase: Pateta toca no café

Relativamente à realização entoacional dos dois grupos rítmicos, constata-se que, nas duas línguas, o primeiro grupo apresenta-se sempre de forma bastante distinta, com o ponto culminante sobre a sílaba acentuada: a segunda, tônica, em português; a terceira, rítmica, em francês. Observa-se também uma ligeira entorse à regra, no caso da declarativa em português, já que a terceira vogal átona de Pateta continua a ser produzida com Fo elevado, fenômeno que pode ser considerado como um efeito acentual, mas sobretudo como um "eco" (com o sentido que lhe é atribuído por Delattre).

Uma ressalva deve ser colocada quanto às diferenças observadas, especialmente para as frases interrogativas. Com efeito, não é de todo impossível que estas diferenças, para além das diferentes estratégias utilizadas, possam refletir igualmente pequenas sutilezas na maneira de colocar a pergunta; por exemplo, uma pergunta retórica, do tipo "Pateta toca no café, não é verdade"?

\section{Estudo da intensidade e da duração das vogais}

\subsection{A intensidade}

É costume dizer-se que o parâmetro de intensidade desempenha um papel pouco importante em francês, quando comparado com 
outras línguas, nomeadamente, com as línguas ditas acentuais. A observação dos gráficos que ilustram a variação deste parâmetro mostra que não há, efectivamente, nenhuma variação significativa da intensidade, o que permitiria detectar claramente os acentos ou os fenómenos demarcativos, independentemente do tipo de frase.

Os gráficos que se seguem, permitem observar, para o francês, a existência de um ponto comum: um decréscimo da intensidade (de 6 a $9 \mathrm{~dB}$ ), sempre sobre a segunda vogal e duas vezes sobre a terceira vogal de Petitout, apesar da presença do acento rítmico na última sílaba ['tu]. Esta constatação é um indício de que este acento será realizado por outros parâmetros, como, por exemplo, Fo. Esta diminuição dos valores da intensidade é, sem dúvida, imputável, pelo menos em parte, à natureza fechada das duas vogais [i] et [u], bem como ao seu ensurdecimento parcial, resultante da presença de uma consoante surda, enfatizado por um fenômeno de palatalização, no caso de [ti]. Em seguida, a intensidade retoma um nível bastante estável, variando apenas de 2 a 3 dB (101-104, 100-103, 103-105, segundo a frase). Em contrapartida, quase nunca se assiste a um decréscimo final da intensidade, facto que poderá parecer surpreendente, visto ser universalmente aceito que as vogais perdem progressivamente a energia no decorrer da realização de qualquer frase.

Em português, de forma invariável, a intensidade atinge um ligeiro ponto máximo sobre as vogais tónicas de Pate ta e de to ca, para, em seguida, decrescer de forma regular, sensivelmente sobre as quatro últimas sílabas da frase, de 4 a 12 dB (103-95, 104-92, 103-99, dependendo da frase). A vogal final, apesar de tónica, sofre sempre uma queda dos valores da intensidade (de 1 a $4 \mathrm{~dB}$ ), relativamente à vogal precedente. Poderemos, por isso, dizer que neste locutor, as variações vão mais de encontro a uma certa lógica esperada, caracterizada por um reforço acentual e um enfraquecimento final (DELGADO-MARTINS, 2002).

No estádio em que se encontra esta pesquisa, embora estas diferenças nas duas línguas se nos apresentem estáveis, parece-nos, no entanto, difícil podermos afirmar se elas desempenham ou não um papel importante na produção e na percepção das frases realizadas. 


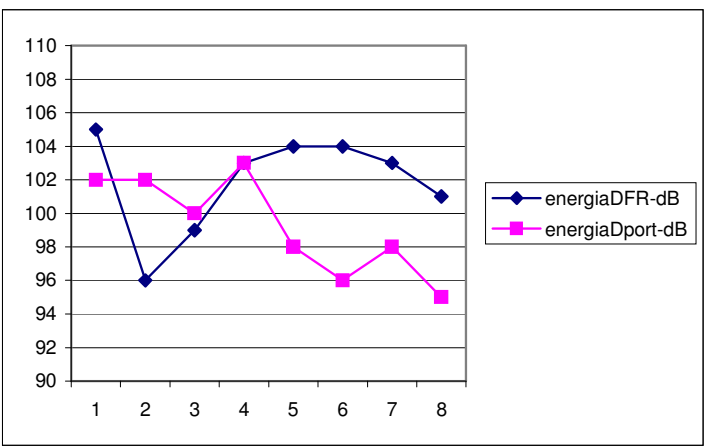

Figura 14 - Comparação da energia vocálica das Declarativas PT/FR

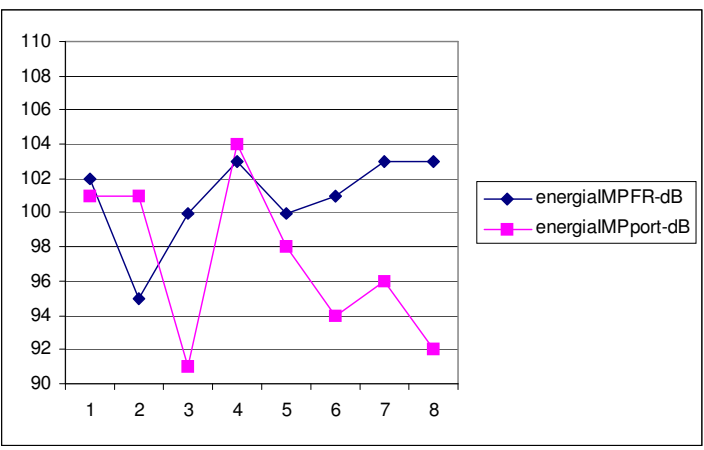

Figura 15 - Comparação da energia vocálica das Imperativas PT/FR

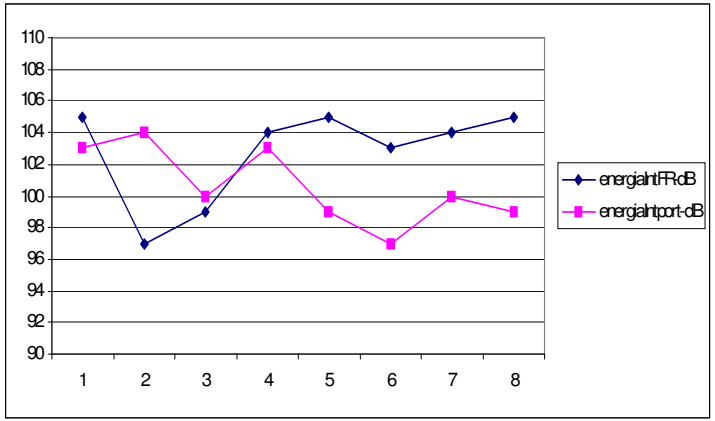

Figura 16 - Comparação da energia vocálica das Interrogativas PT/FR 


\subsection{A duração}

O quadro seguinte, bem como os gráficos construídos com base nos mesmos valores, permitem-nos comparar as três frases nas duas línguas e observar o modo como é utilizado o parâmetro duração. Para além disso, oferece-nos ainda a possibilidade de podermos verificar se existem pontos comuns, quer entre os diferentes tipos de frase, quer entre as duas línguas.

No quadro, inscrevemos, com particular incidência, a duração das vogais que apresentam os valores de duração mais elevados, isto é, com uma duração geralmente superior a $40 / 60 \mathrm{~ms}$. No entanto, uma referência às vogais mais breves é também aí apresentada.

\begin{tabular}{|c|c|c|c|c|c|c|c|c|c|}
\hline \multicolumn{3}{|r|}{1} & 2 & 3 & 4 & 5 & 6 & 7 & 8 \\
\hline \multirow{2}{*}{$\begin{array}{l}\text { tipo de } \\
\text { frase }\end{array}$} & \multirow{2}{*}{$\begin{array}{l}\text { duração } \\
\text { mínima }\end{array}$} & $\mathrm{Pe}$ & tit & tout & passe & à & la & té & lé \\
\hline & & $\mathrm{Pa}$ & te & $\mathrm{ta}$ & to & $\mathrm{ca}$ & no & $\mathrm{ca}$ & fé \\
\hline Dec FR & 39 & & & $64(1,6)$ & $63(1,6)$ & & & & $81(2)$ \\
\hline Dec PT & 31 & $66(2,1)$ & $65(2,1)$ & & $57(1,8)$ & & & & $103(3,3)$ \\
\hline Imp FR & 40 & & & $136(3,4)$ & $70(1,7)$ & & & & $113(2,8)$ \\
\hline Imp PT & 28 & & $108(3,8)$ & & $69(2,5)$ & & & & $82(2,9)$ \\
\hline Int FR & 43 & & & $72(1,7)$ & $54(1,3)$ & & & & $153(3,6)$ \\
\hline Int PT & 26 & $71(2,7)$ & $62(2,4)$ & & $56(2,1)$ & & & & $150(5,8)$ \\
\hline
\end{tabular}

Quadro 5 - Duração média (ms) das vogais mais longas em todas as frases (entre parênteses, a relação com a vogal mais breve da frase; a negrito as vogais nitidamente mais longas)

Constatamos, em primeiro lugar, que as durações vocálicas mais baixas atingem, aproximadamente, $40 \mathrm{~ms}$ para o locutor francês, enquanto que para o português são de $30 \mathrm{~ms}$. Este facto pode parecer surpreendente, visto que o débito de fala do primeiro é ligeiramente superior ao deste último. Atribuímos esta particularidade ao facto de, em português, haver uma tendência para reduzir fortemente as vogais inacentuadas.

Em ambas as línguas, se considerarmos a posição na frase, observamos o seguinte:

- A vogal finalé sempre longa ou muito longa (de 80 à 150 ms): entre 2 a 6 vezes superior às breves. Este facto explica-se certamente 
pela sua posição no fim do primeiro grupo rítmico da frase. Como em português, para além da sua posição no grupo rítmico, também é portadora do acento tónico da última palavra (paroxítona), apresenta-se ainda mais longa do que em francês.

- As vogais não finais, esperadas como acentuadas ou potencialmente acentuadas (acento lexical em português, rítmico em francês), têm igualmente uma duração sempre ligeiramente superior: de 1,3 a 1,8 ms em francês e de 1,8 a 2,7 em português.

Ainda nas duas línguas, se compararmos os dois tipos de frase, constatamos que:

- A declarativa distingue-se essencialmente pela presença de uma vogal final longa (81 e $103 \mathrm{~ms}$ ).

- A imperativa apresenta-se também com uma vogal final longa, com valores semelhantes aos obtidos para a declarativa: 82 e 113 ms. A vogal acentuada do 1o grupo é ainda mais longa, em ambas as línguas (108 e $136 \mathrm{~ms}$ ). O sintagma correspondente ao vocativo é, deste modo, posto ainda mais em relevo do que propriamente a parte final da frase, que contém a ordem.

- Na interrogativa, o final é extremamente longo, para os dois informantes (150 e $153 \mathrm{~ms}$, isto é, respectivamente 3,6 e 5,8 ms superior aos valores obtidos para as vogais breves).

Relativamente às vogais mais breves, o português realiza com maior duração do que o francês as vogais acentuadas. Não deixa de ser surpreendente, porquanto se diz que é o francês que privilegia o parâmetro duração.

Para além disso, o falante português utiliza as variações de alongamento vocálico (relação entre as longas e as breves) de forma superior às utilizadas pelo falante francês. É, sem dúvida, a sua forma de compensar a sua entoação mais monótona, já constatada, e à qual já tivemos ocasião de referirmos noutros momentos. 


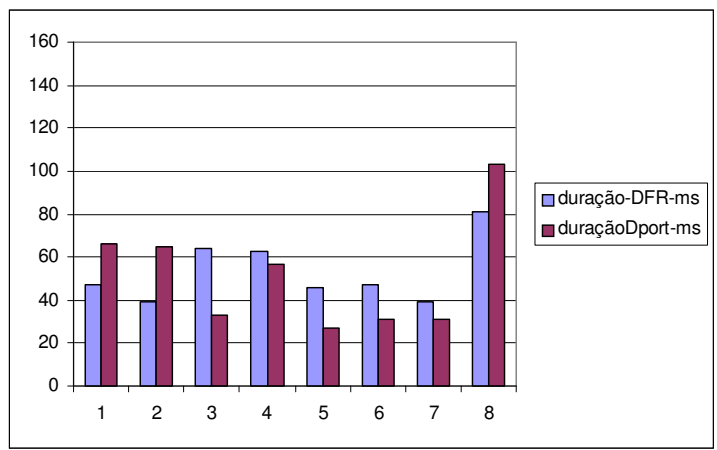

Figura 17 - Comparação das durações vocálicas das declarativas PORT/FR

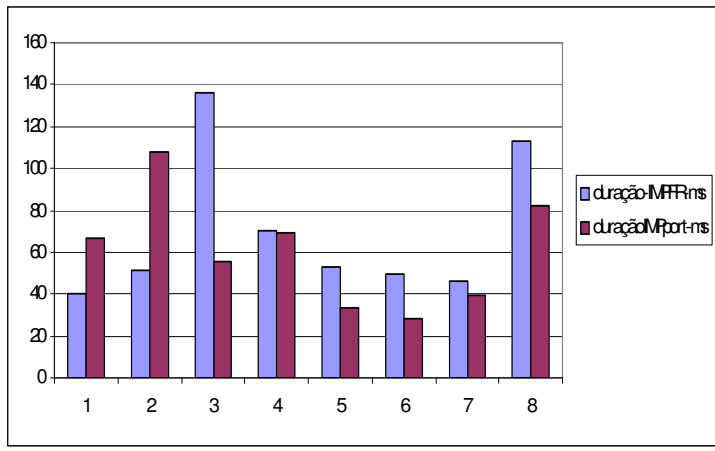

Figura 18 - Comparação das durações vocálicas das imperativas PT/FR

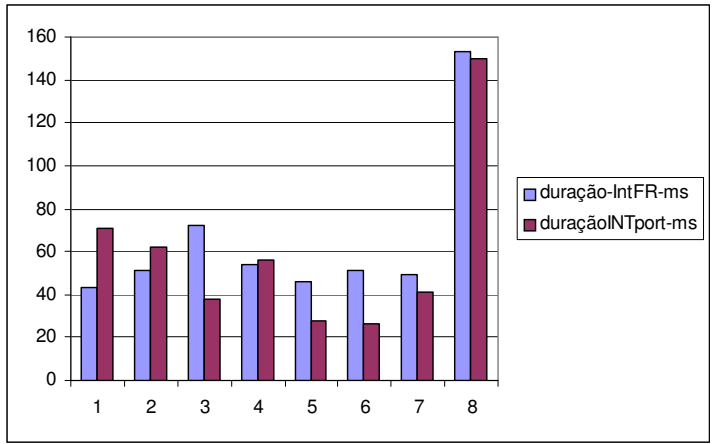

Figura 19 - Comparação das durações vocálicas das interrogativas PT/FR 


\section{SÍNTESE}

Acabamos de verificar, e contrariamente a uma certa expectativa da nossa parte, que o comportamento prosódico das duas línguas, relativamente aos dois locutores estudados, é bastante próximo nos três tipos de frase estudados: declarativa, imperativa e interrogativa.

Para as duas primeiras, as diferenças são mínimas e dizem sobretudo respeito à diferença existente na posição do acento e ao diferente papel por ele desempenhado em cada uma das línguas. Os padrões melódicos e as variações de duração parecem bastante próximos em ambas as línguas.

A diferença mais notória que nós pudemos observar diz respeito às duas diferentes estratégias melódicas utilizadas para a frase interrogativa, embora permaneçam pontos comuns entre as duas línguas, sobretudo no início e fim de frase.

Fica-nos, no entanto, a dúvida sobre os matizes da mensagem que cada informante queria, efectivamente, transmitir quando da formulação da pergunta.

Constatámos que a intensidade não desempenha um papel significativo na distinção entre os três tipos de frases estudados. Parece mais sujeita à variação em português, aumentando ligeiramente para as vogais acentuadas, decrescendo em fim de frase, enquanto que para o francês permanece constante.

Contrariamente a uma ideia pré-concebida, que defende que o francês utiliza essencialmente o parâmetro duração para marcar os acentos, enquanto que as outras línguas utilizariam sobretudo a intensidade e a freqüência fundamental (daí a denominação de "acento tônico"), nos casos analisados, parece ser o português que privilegia aquele parâmetro, sobretudo no caso das vogais acentuadas.

Recorde-se, no entanto, que a frase escolhida para o francês não era propícia ao efeito de alongamento vocálico que geralmente encontramos em certas sílabas fechadas.

Em contrapartida, as variações melódicas globais são claramente superiores no falante francês. Infelizmente, os dados de que dispomos são insuficientes para podermos decidir se trata de um fenómeno passível de ser generalizado às duas línguas estudadas ou 
se deve ser imputado aos locutores. A continuação desta pesquisa é indispensável para clarificar este tipo de problemas.

Para concluir, o quadro seguinte propõe uma síntese das principais características prosódicas comuns às duas línguas, para ambos os informantes.

\begin{tabular}{|c|c|c|c|}
\hline 2 locutores & Declarativa & Imperativa & Interrogativa \\
\hline ataque $\mathrm{Fo}$ & baixo & baixo & alto \\
\hline Fo médio & - & - & + \\
\hline $\begin{array}{l}\text { melodia } \\
\text { grupo } 1\end{array}$ & subida & subida-descida & $\begin{array}{l}\text { ligeira subida } \\
\qquad / \text { forte subida }++(F R)\end{array}$ \\
\hline \& grpo 2 & /descida & /descida & / descida-subida (PT) \\
\hline $\begin{array}{l}\text { duração vocálica } \\
\text { máxima }\end{array}$ & + vogal final & $\begin{array}{r}++ \text { vogal acentuada } 1^{\circ} \text { gr. } \\
+ \text { vogal final }\end{array}$ & ++ vogal final \\
\hline intensidade & & nada de significativo & \\
\hline
\end{tabular}

Quadro 6 - Principais características prosódicas comuns aos dois locutores

\section{CONCLUSÃO}

Como dissemos na introdução, o estudo proposto não é mais do que um esboço sobre os comportamentos prosódicos do francês e do português europeu, realizado de forma não exaustiva. As conclusões apresentadas devem, por isso, ser consideradas com prudência e não permitem, evidentemente, uma generalização, a menos que venham a ser validadas por outras pesquisas posteriores Para além desse aprofundamento, gostaríamos também de dar continuidade a este trabalho, enriquecendo-o com outros esquemas prosódicos e completando esta comparação com outras línguas românicas, como o espanhol e o italiano. O alargamento de uma pesquisa neste domínio, não exclui, a longo prazo, a possibilidade de análise a outras línguas não românicas.

No plano da investigação fundamental, em fonética, os nossos resultados poderão ser comparados com os já obtidos no âmbito do Atlas das línguas românicas (projecto AMPER, já mencionado anteriormente), que tem como objecto de estudo as variedades regionais das línguas românicas. 
No nível das aplicações práticas, e especialmente no domínio do ensino das línguas vivas, estes resultados deveriam permitir, desde já, sublinhar a importância que um aprendente deve dispensar à entoação e ao ritmo, quando se propõe falar uma língua diferente da sua língua materna (FLE, PLE, etc.).

\section{NOTAS}

${ }^{1}$ Projecto do Centre de Dialectologie de Grenoble - Université Stendhal, intitulado AMPER (Atlas Multimédia Prosodique de l'Espace Roman).

${ }^{2}$ Dada a implicação da equipe de Aveiro no projeto AMPER, e os programas de análise de que dispõe para este efeito, decidiu-se adotar uma metodologia de análise semelhante à utilizada no âmbito do referido projeto, especialmente no que diz respeito aos parâmetros estudados.

${ }^{3}$ Note-se que nos gráficos que representam a sobreposição do movimento das curvas melódicas, o primeiro traçado serve de modelo de normalização, inclusive para a escala horizontal. Por isso, a duração dos segmentos correspondem à duração da frase francesa e não à portuguesa.

\section{REFERÊNCIAS BIBLIOGRÁFICAS}

CONTINI, M. Lai J.-P.; ROMANO, A.; ROULLET, S.; MOUTINHO, L. de C.; COIMBRA, R. L.; PEREIRA, B. U.; SECCA RUIVO, S. Un projet d'atlas multimédia prosodique de l'espace roman. Proceedings of the International Conference Speech Prosody 2002. Aix-en-Provence, 11-13 April 2002. p. 227-231.

DELGADO-MARTINS, M. R. (1982). Sept études sur la perception accent et intonation du portugais. Lisboa: INIC, 1986.

DELGADO-MARTINS, M. R. Fonética do português. Trinta anos de investigação. Lisboa: Edit. Caminho, 2002.

DELATTRE, P. Studies in French and comparative phonetics. La Haye: Mouton, 1966.

HIRST, D.; DI CRISTO, A. (Ed.). Intonation systems: a survey of twenty languages. Cambridge: Cambridge University Press, 1998.

MIRA MATEUS, M. H.; DUARTE, I. et al. Gramática da lingua portuguesa. Coimbra: Almedina, 1982. 
MORAIS BARBOSA, J. Entoação e prosódia. In: HOLTUS, G. et al. (Ed.). Lexicon der Romanistischen Linguistik, Band VI, n. 2, p. 243-248, 1994.

MOUTINHO, L. de C.; COIMBRA, R. L.; SECCA RUIVO, S.; PEREIRA, B. U. Atlas Prosódico Multimédia: Curvas de uma Trajectória. Actas do XVIEncontro Nacional da Associação Portuguesa de Linguística, Colibri, p. 387-391, 2001.

MARTIN, P. (1987). Pour une théorie de l'intonation. In: ROSSI et al. p. 234-271, 1981.

ROSSI. L'intonation, le système français. Orphis, 1999. 


\section{ANEXOS}

1 - falante francês - declarativa - medidas médias para as 8 vogais

\begin{tabular}{|c|c|c|c|c|c|}
\hline vogal & $\begin{array}{c}\text { duração } \\
{[\mathrm{ms}]}\end{array}$ & $\begin{array}{c}\text { energia } \\
{[\mathrm{dB}]}\end{array}$ & fo1 & fo2 & $\begin{array}{c}\text { fo3 } \\
{[\mathrm{Hz}]}\end{array}$ \\
\hline 1 & 47 & 105 & 148 & 143 & 143 \\
\hline 2 & 39 & 96 & 170 & 166 & 165 \\
\hline 3 & 64 & 99 & 227 & 219 & 217 \\
\hline 4 & 63 & 103 & 195 & 179 & 175 \\
\hline 5 & 46 & 104 & 162 & 164 & 160 \\
\hline 6 & 47 & 104 & 143 & 140 & 138 \\
\hline 7 & 39 & 103 & 124 & 128 & 127 \\
\hline 8 & 81 & 101 & 103 & 96 & 94 \\
\hline
\end{tabular}

2 - falante francês - imperativa - medidas médias para as 8 vogais

\begin{tabular}{|c|c|c|c|c|c|}
\hline vogal & $\begin{array}{c}\text { duração } \\
{[\mathrm{ms}]}\end{array}$ & $\begin{array}{c}\text { energia } \\
{[\mathrm{dB}]}\end{array}$ & fo1 & fo2 & $\begin{array}{c}\text { fo3 } \\
{[\mathrm{Hz}]}\end{array}$ \\
\hline 1 & 40 & 102 & 131 & 128 & 129 \\
\hline 2 & 51 & 95 & 169 & 160 & 152 \\
\hline 3 & 136 & 100 & 165 & 167 & 148 \\
\hline 4 & 70 & 103 & 216 & 221 & 218 \\
\hline 5 & 53 & 100 & 202 & 186 & 169 \\
\hline 6 & 50 & 101 & 149 & 142 & 139 \\
\hline 7 & 46 & 103 & 132 & 132 & 128 \\
\hline 8 & 113 & 103 & 113 & 109 & 101 \\
\hline
\end{tabular}

3 - falante francês - interrogativa - medidas médias para as 8 vogais

\begin{tabular}{|c|c|c|c|c|c|}
\hline vogal & $\begin{array}{c}\text { duração } \\
{[\mathrm{ms}]}\end{array}$ & $\begin{array}{c}\text { energia } \\
{[\mathrm{dB}]}\end{array}$ & fo1 & fo2 & $\begin{array}{c}\text { fo3 } \\
{[\mathrm{Hz}]}\end{array}$ \\
\hline 1 & 43 & 105 & 126 & 125 & 125 \\
\hline 2 & 51 & 97 & 153 & 152 & 147 \\
\hline 3 & 72 & 99 & 186 & 182 & 174 \\
\hline 4 & 54 & 104 & 165 & 167 & 161 \\
\hline 5 & 46 & 105 & 165 & 162 & 161 \\
\hline 6 & 51 & 103 & 161 & 162 & 165 \\
\hline 7 & 49 & 104 & 183 & 178 & 173 \\
\hline 8 & 153 & 105 & 200 & 229 & 271 \\
\hline
\end{tabular}


4 - falante português - declarativa - medidas médias para as 8 vogais

\begin{tabular}{|c|c|c|c|c|c|}
\hline vogal & $\begin{array}{c}\text { duração } \\
{[\mathrm{ms}]}\end{array}$ & $\begin{array}{c}\text { energia } \\
{[\mathrm{dB}]}\end{array}$ & fo1 & fo2 & $\begin{array}{c}\text { fo3 } \\
{[\mathrm{Hz}]}\end{array}$ \\
\hline 1 & 66 & 102 & 118 & 118 & 118 \\
\hline 2 & 65 & 102 & 128 & 133 & 138 \\
\hline 3 & 33 & 100 & 145 & 141 & 140 \\
\hline 4 & 57 & 103 & 145 & 138 & 138 \\
\hline 5 & 27 & 98 & 142 & 140 & 138 \\
\hline 6 & 31 & 96 & 132 & 132 & 132 \\
\hline 7 & 31 & 98 & 121 & 122 & 122 \\
\hline 8 & 103 & 95 & 100 & 93 & 91 \\
\hline
\end{tabular}

5 - falante português - imperativa - medidas médias para as 8 vogais

\begin{tabular}{|c|c|c|c|c|c|}
\hline vogal & $\begin{array}{c}\text { duração } \\
{[\mathrm{ms}]}\end{array}$ & $\begin{array}{c}\text { energia } \\
{[\mathrm{dB}]}\end{array}$ & fo1 & fo2 & $\begin{array}{c}\text { fo3 } \\
{[\mathrm{Hz}]}\end{array}$ \\
\hline 1 & 67 & 101 & 120 & 122 & 124 \\
\hline 2 & 108 & 101 & 143 & 135 & 118 \\
\hline 3 & 56 & 91 & 102 & 96 & 95 \\
\hline 4 & 69 & 104 & 163 & 159 & 159 \\
\hline 5 & 33 & 98 & 147 & 147 & 146 \\
\hline 6 & 28 & 94 & 133 & 131 & 130 \\
\hline 7 & 39 & 96 & 125 & 118 & 115 \\
\hline 8 & 82 & 92 & 102 & 97 & 92 \\
\hline
\end{tabular}

6 - falante português - interrogativa - medidas médias para as 8 vogais

\begin{tabular}{|c|c|c|c|c|c|}
\hline vogal & $\begin{array}{c}\text { duração } \\
{[\mathrm{ms}]}\end{array}$ & $\begin{array}{c}\text { energia } \\
{[\mathrm{dB}]}\end{array}$ & fo1 & fo2 & $\begin{array}{c}\text { fo3 } \\
{[\mathrm{Hz}]}\end{array}$ \\
\hline 1 & 71 & 103 & 161 & 164 & 171 \\
\hline 2 & 62 & 104 & 185 & 174 & 169 \\
\hline 3 & 38 & 100 & 173 & 167 & 161 \\
\hline 4 & 56 & 103 & 161 & 152 & 155 \\
\hline 5 & 28 & 99 & 157 & 156 & 157 \\
\hline 6 & 26 & 97 & 152 & 151 & 151 \\
\hline 7 & 41 & 100 & 159 & 146 & 147 \\
\hline 8 & 150 & 99 & 113 & 108 & 117 \\
\hline
\end{tabular}

